\title{
Discovery of Nobiletin from Citrus Peel as a Potent Inhibitor of $\beta$-Amyloid Peptide Toxicity
}

\author{
Kumju Youn ${ }^{1,+} \mathbb{C}$, Seonah Lee ${ }^{1,2,+} \mathbb{D}$ and Mira Jun ${ }^{1,2, *}$ \\ 1 Department of Food Science and Nutrition, College of Health Sciences, Dong-A University, 37, \\ Nakdong-daero 550 beon-gil, Saha-gu, Busan 49315, Korea; kjyoun@dau.ac.kr (K.Y.); \\ seonah_lee@daum.net (S.L.) \\ 2 Center for Silver-Targeted Biomaterials, Brain Busan 21 Plus Program, Graduate School, Dong-A University, \\ 37, Nakdong-daero 550 beon-gil, Saha-gu, Busan 49315, Korea \\ * Correspondence: mjun@dau.ac.kr; Tel.: +82-51-200-7323; Fax: +82-51-200-7505 \\ + Contributed equally.
}

Received: 7 October 2019; Accepted: 29 October 2019; Published: 4 November 2019

check for updates

\begin{abstract}
Increasing evidence has demonstrated that amyloid- $\beta$ peptide $(A \beta)$, the hallmark of Alzheimer's disease (AD), evokes oxidative and inflammatory cascades, which ultimately lead to the death of neurons. The purpose of the present study is to demonstrate the effect of nobiletin, a representative compound of citrus peel, in preventive and therapeutic approaches against neuronal damage by exposure to $A \beta_{25-35}$. Nobiletin significantly ameliorated $A \beta_{25-35}$ mediated cell death by restoring abnormal changes in intracellular oxidative stress, cell cycle, nuclear morphology, and activity of apoptotic caspase. Regarding anti-inflammatory responses, nobiletin significantly suppressed interleukin- $1 \beta$, tumor necrosis factor- $\alpha$, nitric oxide $(\mathrm{NO})$, and prostaglandin $\mathrm{E}_{2}$ production in response to $A \beta$ stimulation. Moreover, nobiletin inhibited $A \beta$-stimulated inducible NO synthase and cyclooxygenase- 2 expression, which was attributed to the blockade of nuclear factor- $\kappa \mathrm{B}$ p65 and phosphorylation of its inhibitor, I $k \mathrm{~B}-\alpha$. Interestingly, nobiletin decreased expression of c-Jun N-terminal kinase and p38 without affecting extracellular signal-regulated kinase 1/2 activation. Taken together, the novel data implicate nobiletin as a potential candidate for the prevention of AD through the inhibition of oxidative stress, apoptosis, and inflammation.
\end{abstract}

Keywords: Alzheimer's disease; amyloid- $\beta$ peptide; oxidative stress; inflammation; nobiletin

\section{Introduction}

Amyloid- $\beta$ peptide $(A \beta)$ is the major component of amyloid plaque. $A \beta$ is a characteristic marker of Alzheimer's disease (AD) and is believed to initiate the pathological cascade of the disease. $A \beta$ is a 39 to 43 amino acid peptide formed by $\beta$ - and $\gamma$-secretases that catalyze the splitting of amyloid precursor protein (APP) [1]. A $\beta$ accumulation triggers the cascade of events, such as reactive oxygen species (ROS) production, cell cycle dysregulation, tau phosphorylation, and inflammation, which, ultimately, lead to the death of neurons $[2,3]$.

The detrimental role of $A \beta$ in the stimulation of oxidative stress has been reported in various studies. In a transgenic mouse model, $A \beta$ increased the levels of protein and lipid oxidation markers, including protein carbonyls, 4-hydroxy-2-nonenal, and 3-nitrotyrosine [4,5]. The observed oxidative injury appeared to be dependent on the methionine 35 of $\mathrm{A} \beta$ peptide [6]. Notably, $\mathrm{A} \beta$ can regulate ROS generation and ROS can reciprocally promote overproduction of $A \beta$ in a vicious cycle [7].

Nuclear factor-kappa B (NF-kB) regulates A $\beta$ homeostasis through transcriptional upregulation of various related enzymes and proteins [8]. Under physiological conditions, NF- $\kappa \mathrm{B}$ regulates the expression rates of genes for APP, $\beta$-secretase 1 (BACE1) and several components of the $\gamma$-secretase 
complex. However, activation of NF- $\mathrm{B}$ by $\mathrm{A} \beta$ regulates the transcription of all these genes and over-stimulates A $\beta$ production [9]. Mitogen-activated protein kinases (MAPKs), such as extracellular protein regulated protein kinase (ERK), c-Jun N-terminal kinase (JNK) and p38, can activate the NF- $\kappa B$ pathway to produce a series of inflammatory factors.

Nobiletin (2-(3,4-dimethoxyphenyl)-5,6,7,8-tetramethoxychromen-4-one) is one of the major polymethoxyflavones in the peel of citrus fruits, including oranges, mandarins, limes, and lemons [10]. Various pharmacological effects attributed to nobiletin include antioxidant, anti-inflammatory, anti-diabetic, anti-atherogenic and anti-carcinogenic activities [11-15]. The neuroprotective property of nobiletin has been demonstrated in several recent studies. The compound prevents ischemic brain injury by regulating the Akt/cAMP-response element-binding protein (CREP)/Bcl-2 pathway in Sprague-Dawley rats. Nobiletin reduces A $\beta$-stimulated memory impairment in several AD animal models, including olfactory bulbectomy mice, APP-SL 7-5 Tg mice and 3XTg-AD mice [16-18].

Our previous study demonstrated the ability of nobiletin to non-competitively inhibit BACE1 via hydrogen-bond-mediated interactions with allosteric residues of the enzyme [19]. However, the primary molecular mechanism underlying the neuroprotective effect of nobiletin on $A \beta$-induced oxidative stress and inflammation has not yet been clearly demonstrated, which prompted the present investigation of the possible effects of nobiletin on PC12 cell models.

\section{Materials and Methods}

\subsection{Cell Culture and $A \beta_{25-35}$ Stock Solution}

PC12 cells were cultured in RPMI1640 medium supplemented with 10\% horse serum, 5\% fetal bovine serum, and penicillin (100 U/mL) and treated with nobiletin (Sigma-Aldrich, St. Louis, MO, USA) for $24 \mathrm{~h}$ at $37^{\circ} \mathrm{C}$ in a $5 \% \mathrm{CO}_{2}$ incubator. $\mathrm{A} \beta_{25-35}$ (Sigma-Aldrich) was dissolved in dimethylsulfoxide (DMSO) at an initial concentration of $10 \mathrm{mM}$ and diluted with phosphate buffered saline (PBS). A $\beta_{25-35}$ solution was incubated at $37^{\circ} \mathrm{C}$ for $48 \mathrm{~h}$ to permit aggregation before use.

\subsection{Cell Viability Analysis}

Cell viability was assessed using the established 3-(4,5-dimethylthiazol-2-yl)-2,5-diphenyltetrazolium bromide (MTT) assay. PC12 cells $\left(1 \times 10^{5}\right.$ cells/well in a 96-well plate) were incubated with MTT reagent for $3 \mathrm{~h}$ at $37^{\circ} \mathrm{C}$. The medium was removed and the formazan crystals produced by the reduction of MTT were dissolved in DMSO. The absorbance due to the formazan crystals was measured at $570 \mathrm{~nm}$ using a model ELX808 spectrophotometer (BioTek, Winooski, VT, USA).

\subsection{Intracellular ROS Analysis}

PC12 cells were stained with $\mathrm{CM}-\mathrm{H}_{2}$ DCFDA in minimum essential medium without serum at $37^{\circ} \mathrm{C}$ for $30 \mathrm{~min}$ in the dark and resuspended in Hank's balanced salt solution. Cells were placed on glass slides and cultured overnight. Imaging ROS was done by fluorescence spectrophotometry with excitation and emission wavelengths of 485 and $528 \mathrm{~nm}$, respectively, using a model FLX800 spectrometer (BioTek).

\subsection{Apoptosis Assay by Hoechst 33342 Staining}

PC12 cells were harvested with PBS and fixed in $4 \%$ paraformaldehyde for $20 \mathrm{~min}$ at $25{ }^{\circ} \mathrm{C}$ and then washed with PBS before being exposed to Hoechst 33342 for $15 \mathrm{~min}$ in the dark. The apoptotic morphology was observed using fluorescence microscopy (Olympus Optical Co., Tokyo, Japan) at 400× magnification. 


\subsection{Fluorescence-Activated Cell Sorting (FACS) Analysis}

PC12 cells were cultured in 24 -well plates $\left(5 \times 10^{5}\right.$ cells/well) and incubated with $50 \mu \mathrm{M} \mathrm{A} \beta_{25-35}$ for $24 \mathrm{~h}$ after pretreatment with various concentrations of nobiletin for $1 \mathrm{~h}$. After incubation, cells were collected and analyzed using the Muse ${ }^{\mathrm{TM}}$ Cell Analyzer (Merck Millipore, Darmstadt, Germany). Briefly, FACS analysis following staining with annexin V and 7-aminoactinomycin D (7-AAD) was performed to detect apoptosis, and cell viability was determined using a DNA-binding dye. Cells were fixed in cold $70 \%$ ethanol and stained with propidium iodide (PI), a membrane impermeant dye, to analyze the cell cycle.

\subsection{Assessment of Levels of Nitric Oxide (NO) and Prostaglandin E2 (PGE $\left.E_{2}\right)$}

PC12 cells $\left(2 \times 10^{6}\right)$ were seeded on 6-cell plates containing medium and incubated with $\mathrm{A} \beta_{25-35}$ for $24 \mathrm{~h}$ in the presence or absence of nobiletin. The formation of $\mathrm{NO}_{2}{ }^{-}$, a stable end product that has been extensively used as an indicator of NO accumulation, was assessed using Griess reagent. The media were mixed with Griess reagent at RT for $10 \mathrm{~min}$ and the NO levels were analyzed using the aforementioned ELX808 microplate reader at $570 \mathrm{~nm}$.

The supernatants were mixed with primary antibody solution and $\mathrm{PGE}_{2}$ conjugate for $2 \mathrm{~h}$, followed by washing and addition of stop solution. The absorbance was measured at $450 \mathrm{~nm}$ using the ELX808 microplate reader.

\subsection{Western Blot Analysis}

Proteins ( $40 \mu \mathrm{g}$ ) were separated by $10 \%$ sodium dodecyl sulfate-polyacrylamide gel electrophoresis and transferred to polyvinylidene difluoride (PVDF) membranes. The blots were blocked for $2 \mathrm{~h}$ at RT with 5\% skim milk in $0.1 \%$ Tween 20 in PBS (PBST) and then incubated overnight with specific primary antibodies at $4{ }^{\circ} \mathrm{C}$. The primary antibodies used were against $\beta$-actin (1:1000), tumor necrosis factor-alpha (TNF- $\alpha$; 1:1000), cyclooxygenase-2 (COX-2; 1:1000), inducible NO synthase (iNOS; 1:1000), p-65 (1:1000), phospho (p)-IKB- $\alpha$ (1:1000), p-JNK (1:1000), p-p38 (1:1000), and p-ERK (1:1000). Subsequently, horseradish peroxidase (HRP)-conjugated anti-rabbit IgG secondary antibody or anti-goat IgG was used. Protein bands were visualized using the EZ-capture device (Atto, Tokyo, Japan).

\subsection{Statistical Analysis}

Statistical analysis was performed using SAS 9.3 software (SAS Institute Inc., Cary, NC, USA). All results are expressed as mean \pm SD and are representative of the data obtained from three independent experiments. Statistical comparisons of differences between groups were performed through the Student's $t$ test, considering ${ }^{*} p<0.05$, ${ }^{* *} p<0.01$, and ${ }^{* * *} p<0.001$ as being statistically significant.

\section{Results and Discussion}

\subsection{Nobiletin Inhibits Cytotoxicity Evoked by $A \beta_{25-35}$}

To verify the neuroprotective effect of nobiletin, cell viability was assessed using the MTT assay and FACS. As shown in Figure 1a, nobiletin did not adversely affect PC12 cell viability at concentrations of 1 to $25 \mu \mathrm{M}$, which were used for further study. Treatment with $50 \mu \mathrm{M} \mathrm{A} \beta_{25-35}$ for $24 \mathrm{~h}$ induced approximately $40 \%$ cell death in comparison with the control group $(p<0.001$; Figure $1 \mathrm{~b}$ ). However, pretreatment with 1,10 , and $25 \mu \mathrm{M}$ nobiletin significantly increased cell viability up to $78.1 \% \pm 7.4 \%, 81.3 \% \pm 4.5 \%$, and $82.4 \% \pm 4.7 \%$, respectively. Notably, $10 \mu \mathrm{M}$ nobiletin exhibited a similar neuroprotective effect to that of resveratrol, a well-known positive control. Consistent with the results of the MTT assay, nobiletin significantly prevented $A \beta_{25-35}$-induced cell death in FACS analysis (Figure 1c), and this effect was dependent on the dose of nobiletin. These data provided correlative evidence indicating that nobiletin contributes to cell survival in PC12 cells damaged by $\mathrm{A} \beta_{25-35}$. 


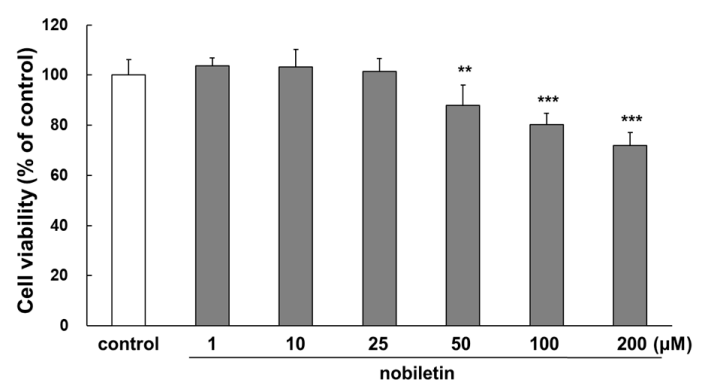

(a)

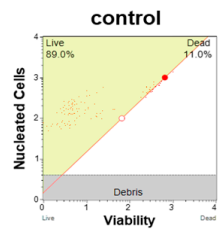

A $\beta+$ nobiletin $10 \mu \mathrm{M} \quad A \beta+$ nobiletin $25 \mu \mathrm{M} \quad \mathrm{A} \beta+$ resveratrol $50 \mu \mathrm{M}$

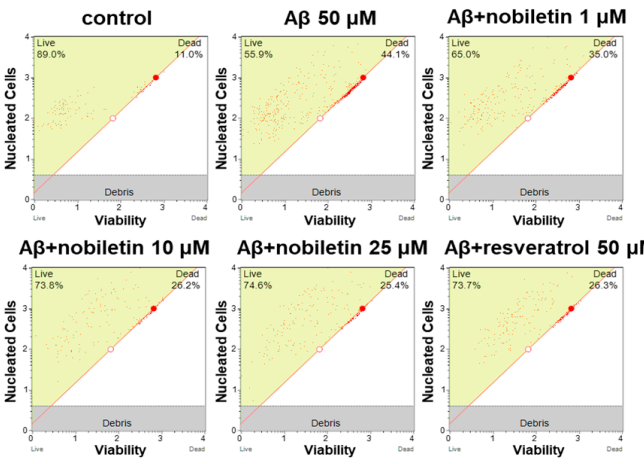

(c)
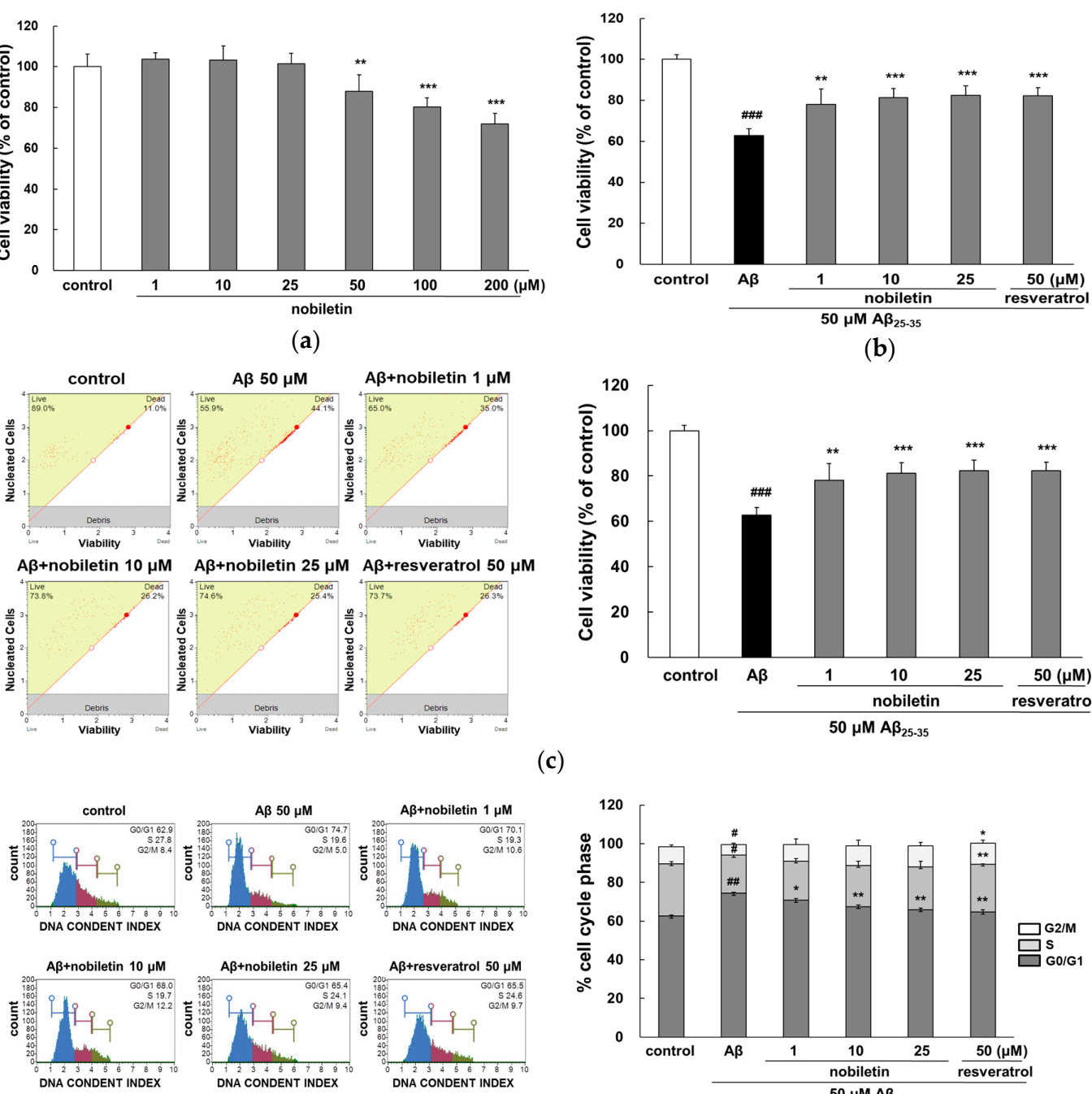

(b)
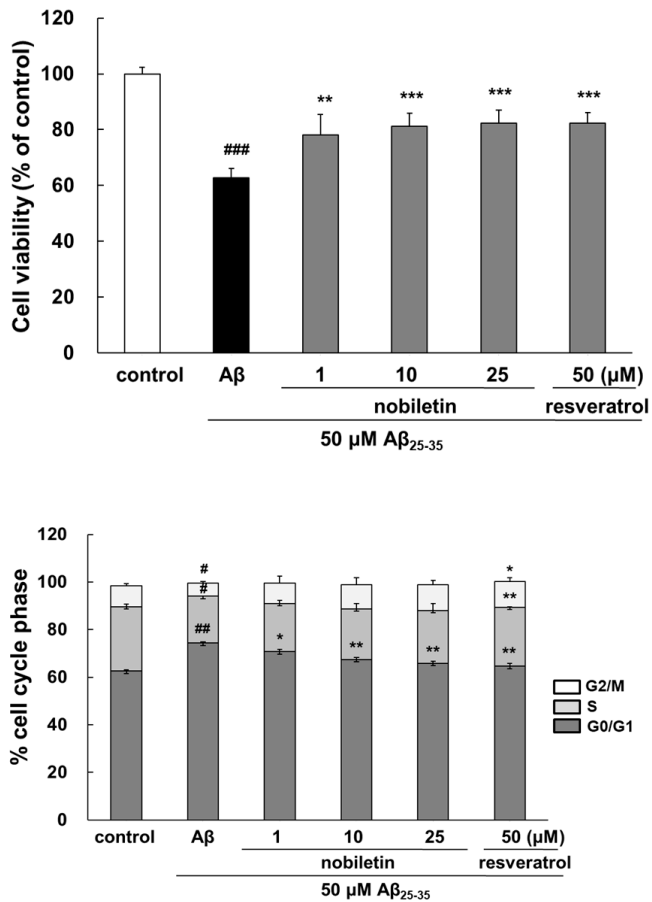

(d)

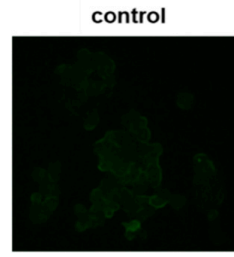

$A \beta 50 \mu \mathrm{M}$

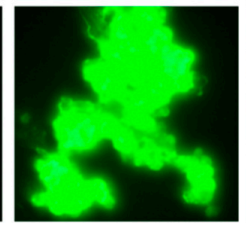

$A \beta+$ nobiletin $1 \mu \mathrm{M}$

$A \beta+$ nobiletin $10 \mu \mathrm{M}$
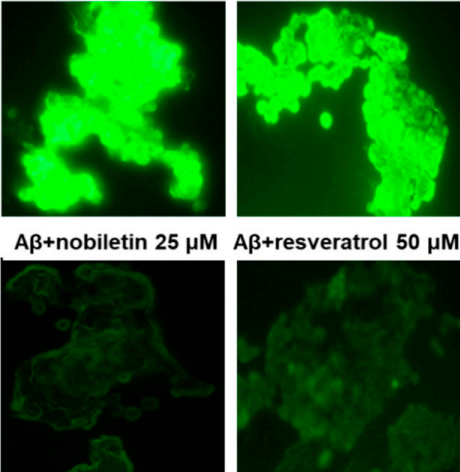

$\mathrm{A} \beta+$ resveratrol $50 \mu \mathrm{M}$
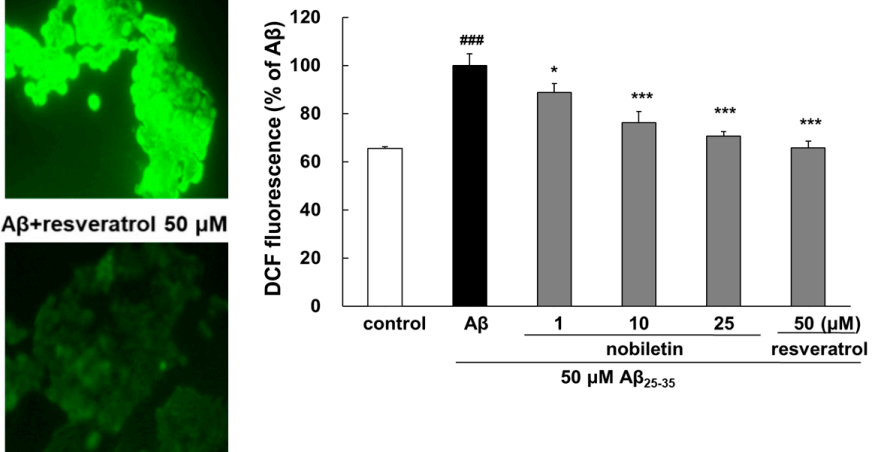

(e)

Figure 1. Protective properties of nobiletin against $A \beta_{25-35}$-mediated cell damage. (a) Evaluation of cytotoxicity nobiletin alone in PC12 cells. Cells were pretreated with nobiletin for $1 \mathrm{~h}$ followed by exposure to $50 \mu \mathrm{M}$ of $\mathrm{A} \beta_{25-35}$ for $24 \mathrm{~h}$, and cell viability was assessed by (b) MTT reduction assay and (c) fluorescence-activated cell sorting (FACS) analysis. (d) Cell cycle progression was measured by FACS. The percentage of cells in the $G_{0} / G_{0}, S$, and $G_{0} / M$ phases of the cell cycle was determined using the Muse 1.5 Analysis software. (e) Intracellular ROS production was observed by CM- $\mathrm{H}_{2} \mathrm{DCFDA}$ fluorescent dye. ${ }^{\# \#} p<0.001,{ }^{\# \#} p<0.01$, and ${ }^{\#} p<0.05$ vs. control. ${ }^{* * *} p<0.001,{ }^{* *} p<0.01$, and * $p<0.05$ vs. $\mathrm{A} \beta_{25-35}$. 
Cell cycle regulation is a crucial process of cell growth and proliferation in neurons [20]. As shown in Figure $1 d, A \beta_{25-35}$ significantly induced an increase in cells in the $G_{0} / G_{1}$ phase $(p<0.01)$ and a corresponding decrease in cells in the $S$ phase and $G_{2} / M$ phase $(p<0.05)$, suggesting that cells had lower rates of growth and tended to be arrested at the $G_{0} / G_{1}$ transition. However, nobiletin restored $\mathrm{A} \beta_{25-35}$-mediated cell cycle dysregulation in a concentration-dependent manner, which may contribute to the enhanced cell viability effect of the compound.

Nobiletin was further evaluated for its antioxidant property in $\mathrm{A} \beta_{25-35}$-injured cells by ROS regulation. As indicated in Figure 1e, fluorescence intensity and large numbers of bright particles in cells were visibly increased by $\mathrm{A} \beta_{25-35}$ exposure, suggesting the presence of intracellular oxidative stress. $\mathrm{A} \beta_{25-35}$ stimulated significant increase in ROS to $100 \% \pm 4.86 \%(p<0.001)$. However, pretreatment of nobiletin decreased ROS generation in a dose-dependent manner $(p<0.05$ and $p<0.001)$. These data were consistent with previous descriptions of the antioxidant property of nobiletin. The compound protected PC12 cells against $\mathrm{H}_{2} \mathrm{O}_{2}$-triggered damage by scavenging ROS, decreasing malonaldehyde (MDA), and enhancing glutathione (GSH) and superoxide dismutase (SOD) contents [21]. In addition, excessive intracellular ROS stimulates the activation of signal transduction cascades, which disturbs calcium homeostasis and leads to the initiation of apoptosis. Nobiletin prevents mitochondrial calcium overload as well as ROS generation in glutamate-induced cortical neurons [22]. In vivo, the intraperitoneal administration of nobiletin reportedly reduced tau phosphorylation, the index of protein oxidation, and protein carbonyl levels in SAMP8 mice, which were related to the recovery of GSH/glutathione disulfide (GSSG) ratio and increased glutathione peroxidase (GPx) activity [23]. These results demonstrated that the neuroprotective role of nobiletin results, at least in part, from the reduction of oxidative stress.

\subsection{Nobiletin Reduces $A \beta_{25-35}$-Mediated Apoptosis and Caspase-3 Activation}

Intracellular oxidative stress plays a central role in the induction of neuronal apoptosis stimulated by $A \beta$ [24]. As shown in Figure $2 a$, cells treated with $A \beta_{25-35}$ exhibited uneven morphology of their nuclei as a result of membrane blebbing, chromatin aggregation, and nuclear condensation, whereas the nobiletin pretreated group showed dispersed and weak fluorescence that is typical of live cells. Particularly, nobiletin at $25 \mu \mathrm{M}$ decreased apoptosis similar to the level of the positive control group. Analysis of morphology alone is not sufficient to distinguish between early and late apoptotic cells. Thus, flow cytometric analysis was employed to quantitatively analyze apoptotic cell death. When exposed to $A \beta_{25-35}$, early and late apoptosis was significantly increased to $26.39 \% \pm 2.48 \%$ and $29.06 \% \pm 2.33 \%$, respectively, compared with the control group $(p<0.001$, Figure $2 b)$. Nobiletin—at all concentrations - markedly reduced both early and late apoptosis. These results were consistent with the anti-apoptotic activity of nobiletin in endoplasmic reticulum stress-induced PC12 and I/R-exposed Kupffer cells [25].

Caspase-3 is a biomarker of oxidative-stress-stimulated cell death that has also been implicated in the final stage of apoptosis. The caspase- 3 was obviously activated in the $\mathrm{A} \beta_{25-35}$-treated group $(p<0.001$, Figure 2c). However, enhanced caspase- 3 activity was dose-dependently decreased by nobiletin. A $\beta$-triggered apoptotic cell death is related to the reduced anti-apoptotic Bcl-2 protein and the increased pro-apoptotic molecule Bax expression. In a previous study, nobiletin displayed an anti-apoptosis effect by decreasing the ratio of Bcl-2/Bax expression in $\mathrm{H}_{2} \mathrm{O}_{2}$-stimulated HT22 cells [26]. 

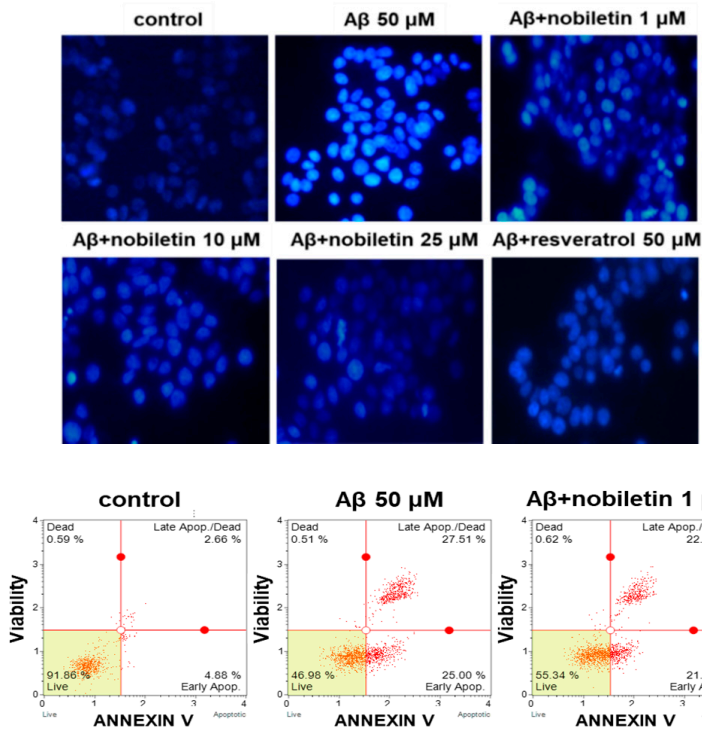

$A \beta+$ nobiletin $10 \mu \mathrm{M}$
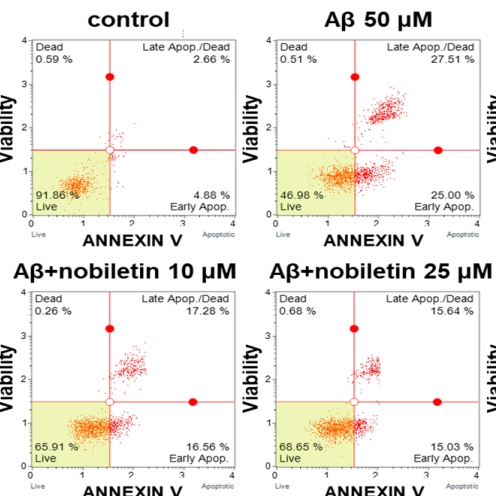

A
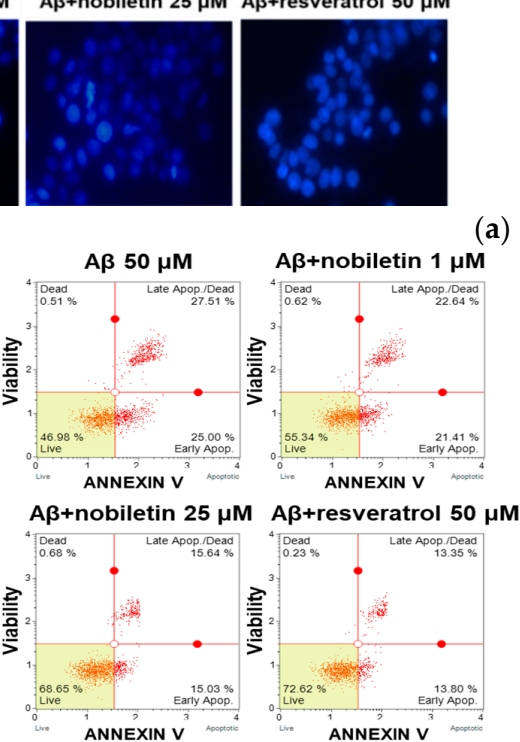

(a)

$A \beta+$ nobiletin $1 \mu M$
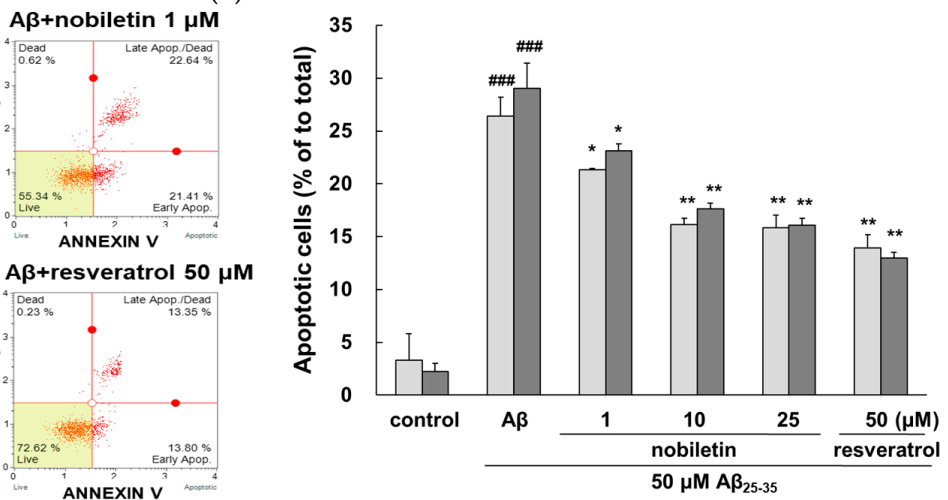

(b)

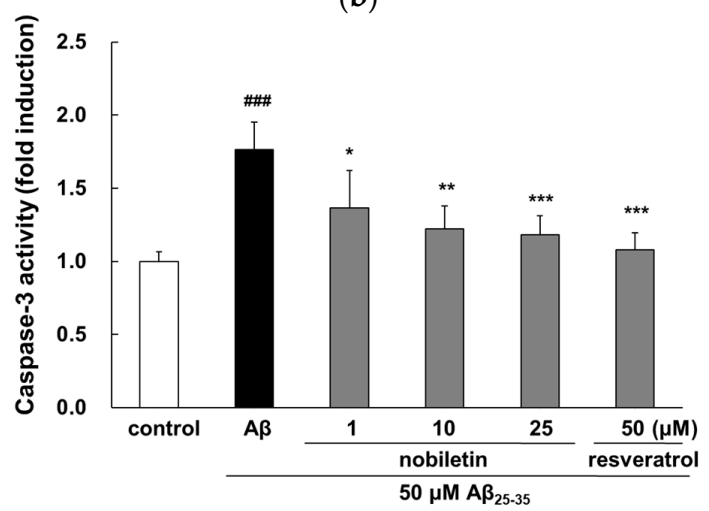

(c)

Figure 2. Activity of nobiletin in preventing $A \beta_{25-35}$-evoked apoptosis and caspase-3. (a) Morphological features of apoptotic cells were observed by fluorescence microscopy using Hoechst 33342 staining (magnification $\times 400$ ). (b) Flow cytometric analysis was used to investigate the properties of nobiletin on $A \beta_{25-35}$-stimulated apoptosis. The cell populations discriminated in each quadrant are live cells in the lower-left quadrant, early apoptotic cells in the lower-right quadrant, late apoptotic cells in the upper-right quadrant, and dead cells in the upper-left quadrant. (c) Caspase-3 activity was assessed using the caspase- 3 assay kit. ${ }^{\# \# \#} p<0.001$ vs. control. ${ }^{* * *} p<0.001,{ }^{* *} p<0.01$, and ${ }^{*} p<0.05$ vs. A $\beta_{25-35}$.

\subsection{Nobiletin Suppresses $A \beta_{25-35}$-Induced Release of Inflammatory Markers}

$A \beta_{25-35}$ exposure increases the release of $\mathrm{NO}$ and $\mathrm{PGE}_{2}$ by approximately 5-fold compared with the control (Figure 3a,b). Notably, treatment with 10 and $25 \mu \mathrm{M}$ nobiletin exhibited similar activity as that of $50 \mu \mathrm{M}$ resveratrol. $A \beta_{25-35}$ treatment increased the expression level of pro-inflammatory cytokines, such as TNF- $\alpha$ and interleukin (IL)-1 $\beta$, by 3-fold (Figure 3c), but the expressions were suppressed by 10 and $25 \mu \mathrm{M}$ nobiletin.

As shown in Figure 3d, the level of iNOS stimulated by $A \beta_{25-35}$ increased up to $202.5 \% \pm 18.3 \%$ compared with the control $(p<0.001)$. However, nobiletin promptly inhibited the expression of iNOS 
protein. Notably, the highest concentration of nobiletin resulted in almost complete suppression of the enzyme production $(118.3 \% \pm 15.7 \% ; p<0.001)$. In parallel, $\mathrm{A} \beta_{25-35}$-mediated COX-2 expression was also markedly blocked by nobiletin.

Several studies have demonstrated that nobiletin possesses strong anti-inflammatory ability in lipopolysaccharide (LPS)-induced expression of pro-inflammatory cytokines in BV2 microglial cells [27-29]. A recent in vivo study suggested that the oral administration of nobiletin (100 mg/kg/day) for 6 weeks attenuated microglial activation and secretion of pro-inflammatory mediators, leading to the restoration of memory deficits in mice [30].

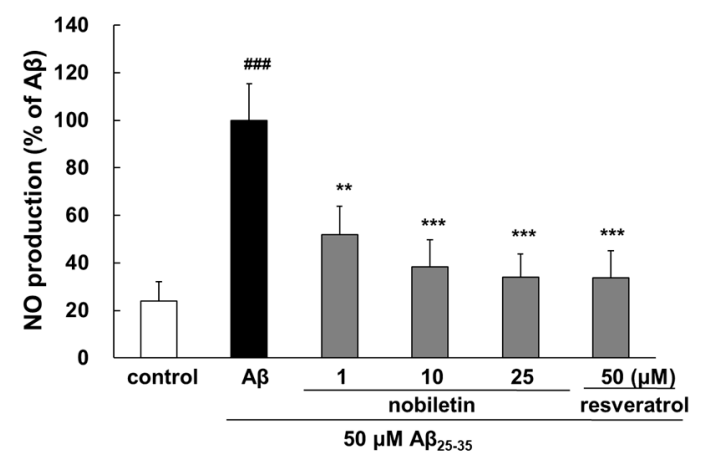

(a)
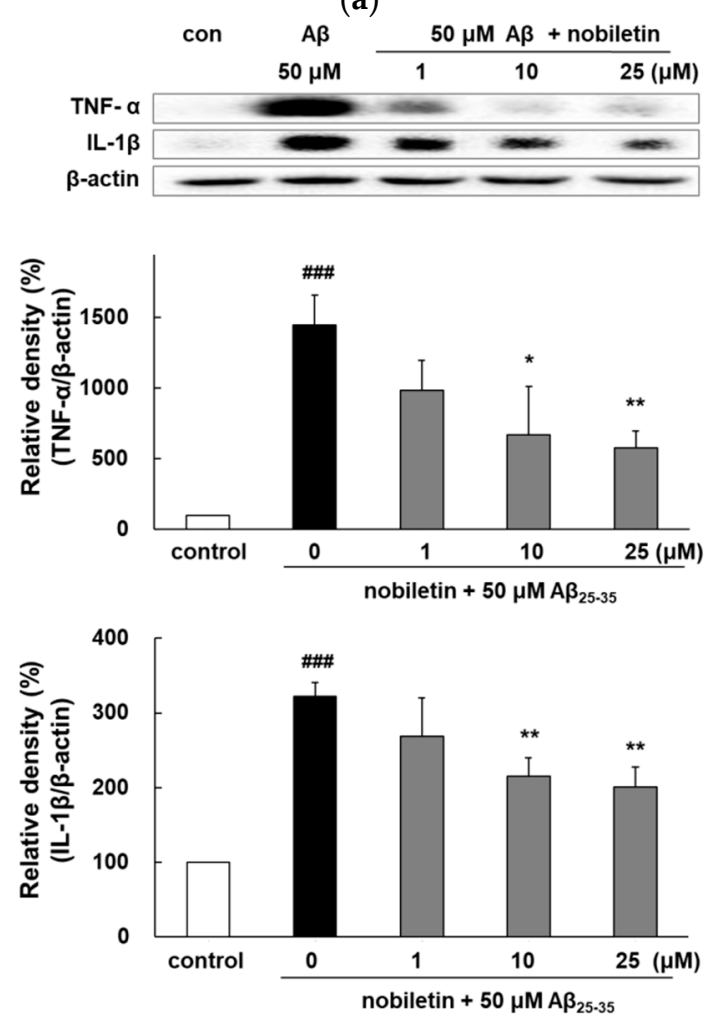

(c)

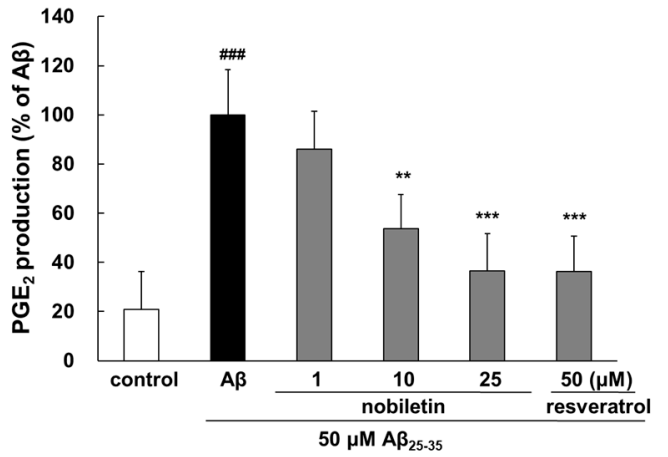

(b)
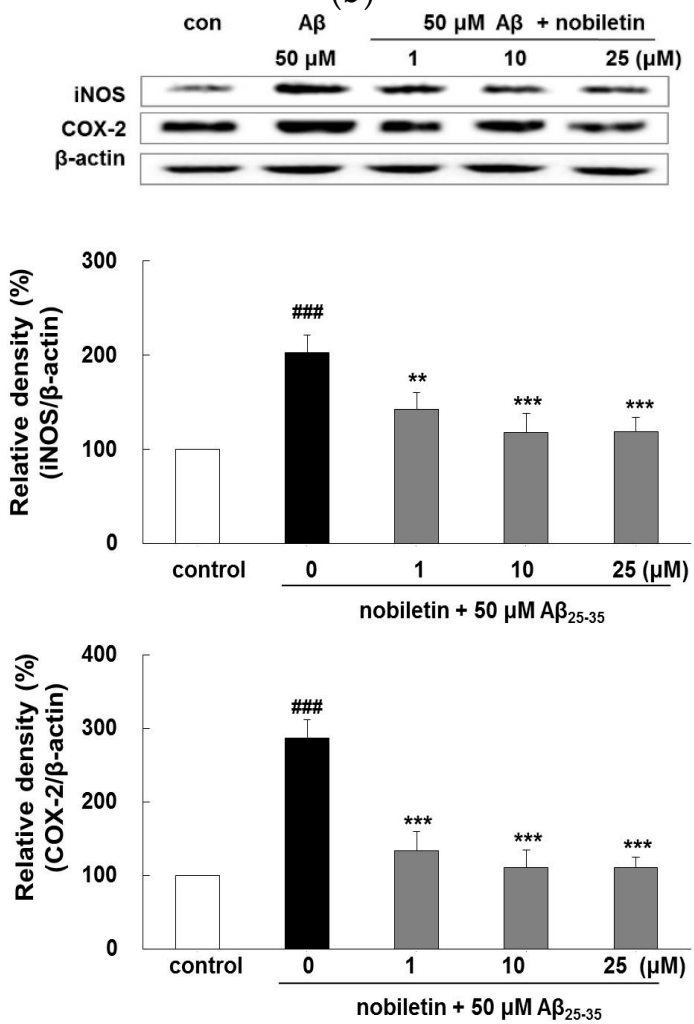

(d)

Figure 3. Inhibitory properties of nobiletin on $A \beta_{25-35}$-mediated expression of (a) NO, (b) $\mathrm{PGE}_{2}$, (c) TNF- $\alpha$ and IL- $\beta$, and (d) iNOS and COX-2 in PC12 cells. The cells were pretreated with nobiletin for $1 \mathrm{~h}$ and then exposed to $A \beta_{25-35}$ for $24 \mathrm{~h}$. The culture supernatant was collected to evaluate the NO and PGE $_{2}$ formation. Protein expression of TNF- $\alpha$, IL- $\beta$, iNOS, and COX- 2 was measured by Western blot analysis. The band intensities were quantified using Image J software and normalized to $\beta$-actin. \#\#\# $p<0.001$ vs. control. ${ }^{* * *} p<0.001{ }^{* *} p<0.01$, and ${ }^{*} p<0.05$ vs. $\mathrm{A} \beta_{25-35}$. 


\subsection{Nobiletin Regulates $A \beta_{25-35}$-Induced NF- $\kappa B$ and MAPK Signaling Pathways}

$\mathrm{A} \beta_{25-35}$ obviously elevated the phosphorylation of p65 and IкB- $\alpha$ by $227.4 \% \pm 19.6 \%$ and $194.4 \% \pm 10.1 \%$, respectively. In contrast, pretreatment with nobiletin at 10 and $25 \mu \mathrm{M}$ remarkably repressed p65 expression (Figure 4a). Moreover, in the case of IKB- $\alpha$, all doses of nobiletin indicated a significant inhibitory effect in respect to $A \beta_{25-35}$ treatment.
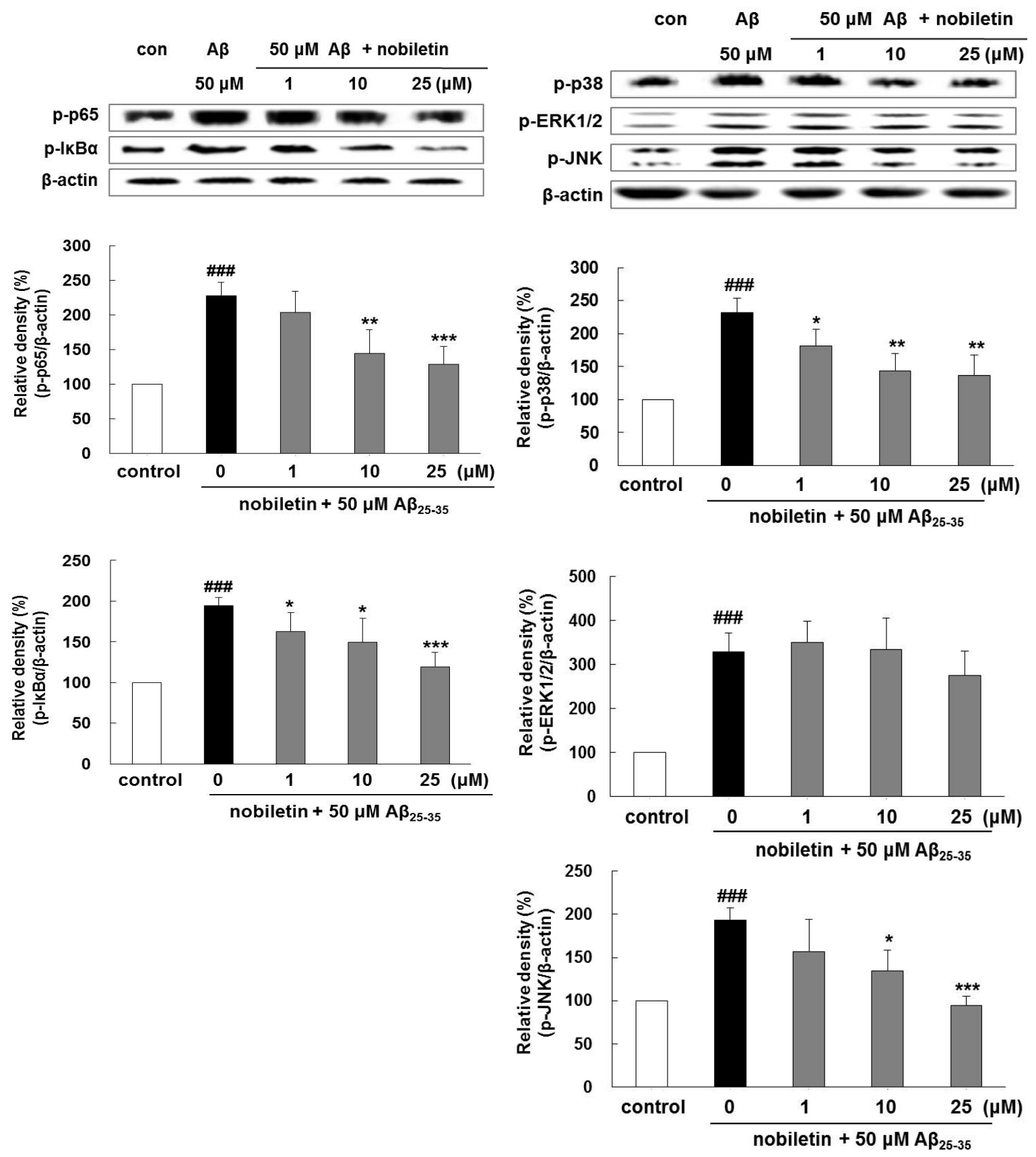

(a)

(b)

Figure 4. Inhibitory properties of nobiletin in the NF- $\mathrm{KB} / \mathrm{MAPKs}$ pathway. Phosphorylation of (a) p65 and IKB- $\alpha$, and (b) p38, ERK1/2, and JNK was examined by Western blot analysis. The cells were pretreated with nobiletin for $1 \mathrm{~h}$ and then exposed to $\mathrm{A} \beta_{25-35}$ for $4 \mathrm{~h}$ (p65 and IKB- $\alpha$ ) or $1 \mathrm{~h}$ (p38, ERK1/2, and JNK). Quantification of band intensities was conducted using Image J software and normalized to $\beta$-actin. ${ }^{\# \# \#} p<0.001$ vs. control. ${ }^{* * *} p<0.001,{ }^{* *} p<0.01$, and ${ }^{*} p<0.05$ vs. $\mathrm{A} \beta_{25-35}$. 
As presented in Figure $4 \mathrm{~b}$, nobiletin suppressed $\mathrm{A} \beta_{25-35}$-evoked phosphorylation of $\mathrm{p} 38$ and JNK. In particular, the level of phosphorylated JNK was markedly suppressed when treated with $25 \mu \mathrm{M}$ nobiletin $(94.4 \% \pm 9.8 \%, p<0.001)$, indicating that the phosphorylation of MAPKs was closely related with the inhibitory property of nobiletin on $\mathrm{A} \beta_{25-35}$-evoked activation of $\mathrm{p} 65$ and IKB- $\alpha$.

Previous research has reported that BACE1 promoter transactivation is modulated by the NF- $\mathrm{kB}$ signaling pathway, indicating that the suppression of NF-KB leads to inhibition of BACE1 activity [9]. In our previous study, we observed that nobiletin blocked BACE1 activity, suggesting that the compound might modulate BACE1 activation by suppressing the NF- $\mathrm{KB}$ signaling pathway [19]. Another study reported that nobiletin inhibited $\mathrm{H}_{2} \mathrm{O}_{2}$-evoked cell death in HT22 murine hippocampal cells, accompanied by decreased JNK and p38 phosphorylation [26]. In rat primary astrocytes, nobiletin suppressed the overexpression of iNOS and NO by the inhibition of the NF- $\mathrm{BB} / \mathrm{p} 38$ MAPK pathways.

Several animal studies clearly demonstrated that nobiletin $(10-50 \mathrm{mg} / \mathrm{kg})$ improves memory in rats exposed to chronic intracerebroventricular infusion of $A \beta_{1-40}$ [31]. In addition, daily supplementation of nobiletin $(10 \mathrm{mg} / \mathrm{kg})$ for 4 months significantly lowers both $\mathrm{A} \beta_{1-40 / 42}$ and amyloid plaques in 9-month-old APP-SL 7-8 Tg mice [17]. Recently, Nakajima et al. demonstrated that nobiletin (10 mg/kg) reduces tau phosphorylation in SAMP8 mice [23].

Bioavailability is an essential factor for the development of potential therapeutic agents. In addition, the anti-AD agents must penetrate the blood-brain barrier to attain sufficient concentration for the therapeutic application within the central nervous system. When nobiletin $(50 \mathrm{mg} / \mathrm{kg})$ was administered, the content of intact nobiletin was detected in rat brains within $1 \mathrm{~h}$ after dosing, suggesting that this compound can rapidly cross the blood-brain barrier and reach the brain. Furthermore, the concentration of nobiletin was 2.4-fold higher in the brain than in plasma. Interestingly, nobiletin was detected for up to $24 \mathrm{~h}$ in the brain, whereas in the plasma, it was observed up to $9 \mathrm{~h}$, suggesting that elimination of this compound from the brain was slower in comparison to plasma [32]. Of note, nobiletin has no discernible toxicity in chronic treatments in mice and humans [33].

\section{Conclusions}

The novel results of the present study indicate that nobiletin, a natural compound in citrus peel, has a neuroprotective effect on $\mathrm{A} \beta_{2} 5-35$-induced cytotoxic damage of PC12 cells. The data may provide a preventive and/or therapeutic potential of nobiletin for degenerative disorders of the brain.

Author Contributions: Data curation, S.L.; writing-original draft, K.Y.; supervision, review \& editing, M.J.

Funding: This research was funded by Dong-A University.

Conflicts of Interest: All authors declare no conflict of interest.

\section{References}

1. Selkoe, D.J. Translating cell biology into therapeutic advances in Alzheimer's disease. Nature 1999, 399, A23-A31. [CrossRef] [PubMed]

2. Shen, Y.; He, P.; Zhong, Z.; McAllister, C.; Lindholm, K. Distinct destructive signal pathways of neuronal death in Alzheimer's disease. Trends Mol. Med. 2006, 12, 574-579. [CrossRef] [PubMed]

3. Butterfield, D.A.; Drake, J.; Pocernich, C.; Castegna, A. Evidence of oxidative damage in Alzheimer's disease brain: Central role for amyloid beta-peptide. Trends Mol. Med. 2001, 12, 548-554. [CrossRef]

4. Garcia-Alloza, M.; Dodwell, S.A.; Meyer-Luehmann, M.; Hyman, B.T.; Bacskai, B.J. Plaque-derived oxidative stress mediates distorted neurite trajectories in the Alzheimer mouse model. J. Neuropathol. Exp. Neurol. 2006, 65, 1082-1089. [CrossRef]

5. Robinson, R.A.; Lange, M.B.; Sultana, R.; Galvan, V.; Fombonne, J.; Gorostiza, O.; Zhang, J.; Warrier, G.; Cai, J.; Pierce, W.M.; et al. Differential expression and redox proteomics analyses of an Alzheimer disease transgenic mouse model: Effects of the amyloid- $\beta$ peptide of amyloid precursor protein. Neuroscience 2011, 177, 207-222. [CrossRef] [PubMed] 
6. Butterfield, D.A.; Sultana, R. Methionine-35 of A $\beta$ (1-42): Importance for oxidative stress in Alzheimer disease. J. Amino Acid. 2011, 2011, 198430. [CrossRef] [PubMed]

7. Wojsiat, J.; Zoltowska, K.M.; Laskowska-Kaszub, K.; Wojda, U. Oxidant/Antioxidant imbalance in alzheimer's disease: Therapeutic and diagnostic prospects. Oxid. Med. Cell Longev. 2018, 2018, 6435861. [CrossRef]

8. Chen, C.H.; Zhou, W.; Liu, S.; Deng, Y.; Cai, F.; Tone, M.; Tone, Y.; Tong, Y.; Song, W. Increased $\mathrm{NF}-\kappa \mathrm{B}$ signalling up-regulates BACE1 expression and its therapeutic potential in Alzheimer's disease. Int. J. Neuropsychopharmacol. 2012, 15, 77-90. [CrossRef]

9. Chami, L.; Buggia-Prévot, V.; Duplan, E.; Del Prete, D.; Chami, M.; Peyron, J.F.; Checler, F. Nuclear factor- $\mathrm{KB}$ regulates $\beta \mathrm{APP}$ and $\beta$ - and $\gamma$-secretases differently at physiological and supraphysiological $\mathrm{A} \beta$ concentrations. J. Biol. Chem. 2012, 287, 24573-24584. [CrossRef]

10. Nogata, Y.; Sakamoto, K.; Shiratsuchi, H.; Ishii, T.; Yano, M.; Ohta, H. Flavonoid composition of fruit tissues of citrus species. Biosci. Biotechonol. Biochem. 2006, 70, 178-192. [CrossRef]

11. Wang, M.; Meng, D.; Zhang, P.; Wang, X.; Du, G.; Brennan, C.; Li, S.; Ho, C.T.; Zhao, H. Antioxidant protection of nobiletin, 5-dimethylnobiletin, tangeretin, and 5-demethyltangeretin from citrus peel in Sacch. Cerevisiae. J. Agric. Food Chem. 2018, 66, 3155-3160. [CrossRef] [PubMed]

12. Choi, S.Y.; Hwang, J.H.; Ko, H.C.; Park, J.G.; Kim, S.J. Nobiletin from Citrus fruit peel inhibits the DNA-binding activity of NF-kappab and ROS production in LPS-activated RAW 264.7 cells. J. Ethnopharmacol. 2007, 113, 149-155. [CrossRef] [PubMed]

13. Lee, Y.S.; Cha, B.Y.; Saito, K.; Yamakawa, H.; Choi, S.S.; Yamaguchi, K.; Yonezawa, T.; Teruya, T.; Nagai, K.; Woo, J.T. Nobiletin improves hyperglycemia and insulin resistance in obese diabetic ob/ob mice. Biochem. Pharmacol. 2010, 79, 1674-1683. [CrossRef] [PubMed]

14. Mulvihill, E.E.; Assini, J.M.; Lee, J.K.; Allister, E.M.; Sutherland, B.G.; Koppes, J.B.; Sawyez, C.G.; Edwards, J.Y.; Telford, D.E.; Charbonneau, A.; et al. Nobiletin attenuates VLDL overproduction, dyslipidemia, and atherosclerosis in mice with diet-induced insulin resistance. Diabetes 2011, 60, 1446-1457. [CrossRef] [PubMed]

15. Miyamoto, S.; Yasui, Y.; Tanaka, T.; Ohigashi, H.; Murakami, A. Suppressive effects of nobiletin on hyperleptinemia and colitis-related colon carcinogenesis in male ICR mice. Carcinogenesis 2008, 29, 1057-1063. [CrossRef] [PubMed]

16. Nakajima, A.; Yamakuni, T.; Haraguchi, M.; Omae, N.; Song, S.Y.; Kato, C.; Nakagawasai, O.; Tadano, T.; Yokosuka, A.; Mimaki, Y.; et al. Nobiletin, a citrus flavonoid that improves memory impairment, rescues bulbectomy induced cholinergic neurodegeneration in mice. J. Pharmacol. Sci. 2007, 105, 122-126. [CrossRef]

17. Onozuka, H.; Nakajima, A.; Matsuzaki, K.; Shin, R.W.; Ogino, K.; Saigusa, D.; Tetsu, N.; Yokosuka, A.; Sashida, Y.; Mimaki, Y.; et al. Nobiletin, a citrus flavonoid, improves memory impairment and Abeta pathology in a transgenic mouse model of Alzheimer's disease. J. Pharmacol. Exper. Thera. 2008, 326, 739-744. [CrossRef]

18. Nakajima, A.; Aoyama, Y.; Shin, E.J.; Nam, Y.; Kim, H.C.; Nagai, T.; Yokosuka, A.; Mimaki, Y.; Yokoi, T.; Ohizumi, Y.; et al. Nobiletin, a citrus flavonoid, improves cognitive impairment and reduces soluble Abeta levels in a triple transgenic mouse model of Alzheimer's disease (3XTg-AD). Behav. Brain Res. 2015, 289, 69-77. [CrossRef]

19. Youn, K.; Yu, Y.; Lee, J.; Jeong, W.S.; Ho, C.T.; Jun, M. Polymethoxyflavones: Novel $\beta$-secretase (BACE1) inhibitors from Citrus peels. Nutrients 2017, 9, 973. [CrossRef]

20. Giovanni, A.; Wirtz-Brugger, F.; Keramaris, E.; Slack, R.; Park, D.S. Involvement of cell cycle elements, cycline-dependent kinases, pRb, and E2F x DP, in B-amyloid-induced neuronal death. J. Biol. Chem. 1999, 274, 19011-19016. [CrossRef]

21. Lu, Y.H.; Su, M.Y.; Huang, H.Y.; Lin-Li; Yuan, C.G. Protective effects of the citrus flavanones to PC12 cells against cytotoxicity induced by hydrogen peroxide. Neurosci. Lett. 2010, 484, 6-11. [CrossRef] [PubMed]

22. Lee, J.H.; Amarsanaa, K.; Wu, J.; Jeon, S.C.; Cui, Y.; Jung, S.C.; Park, D.B.; Kim, S.J.; Han, S.H.; Kim, H.W.; et al. Nobiletin attenuates neurotoxic mitochondrial calcium overload through $\mathrm{K}+$ influx and $\Delta \Psi \mathrm{m}$ across mitochondrial inner membrane. Korean J. Physiol. Pharmacol. 2018, 3, 311-319. [CrossRef] [PubMed]

23. Nakajima, A.; Aoyama, Y.; Nguyen, T.T.; Shin, E.J.; Kim, H.C.; Yamada, S.; Nakai, T.; Nagai, T.; Yokosuka, A.; Mimaki, Y.; et al. Nobiletin, a citrus flavonoid, ameliorates cognitive impairment, oxidative burden, and hyperphosphorylation of tau in senescence-accelerated mouse. Behav. Brain Res. 2013, 250, 351-360. [CrossRef] [PubMed] 
24. Xian, Y.F.; Lin, Z.X.; Mao, Q.Q.; Ip, S.P.; Su, Z.R.; Lai, X.P. Protective effect of isorhynchophylline against beta-amyloid-induced neurotoxicity in PC12 cells. Cell Mol. Neurobiol. 2012, 32, 353-360. [CrossRef]

25. Li, Z.R.; Yang, L.; Zhen, J.; Zhao, Y.; Lu, Z.N. Nobiletin protects PC12 cells from ERS-induced apoptosis in OGD/R injury via activation of the PI3K/AKT pathway. Exp. Ther. Med. 2018, 16, 1470-1476. [CrossRef]

26. Cho, H.W.; Jung, S.Y.; Lee, G.H.; Cho, J.H.; Choi, I.Y. Neuroprotective effect of Citrus unshiu immature peel and nobiletin inhibiting hydrogen peroxide-induced oxidative stress in HT22 murine hippocampal neuronal cells. Pharmacogn. Mag. 2015, 11, S284-S289. [CrossRef]

27. Cui, Y.; Wu, J.; Jung, S.C.; Park, D.B.; Maeng, Y.H.; Hong, J.Y.; Kim, S.J.; Lee, S.R.; Kim, S.J.; Kim, S.J.; et al. Anti-neuroinflammatory activity of nobiletin on suppression of microglial activation. Biol. Pharm. Bull. 2010, 33, 1814-1821. [CrossRef]

28. Ho, S.C.; Kuo, C.T. Hesperidin, nobiletin, and tangeretin are collectively responsible for the anti-neuroinflammatory capacity of tangerine peel (Citri reticulatae pericarpium). Food Chem. Toxicol. 2014, 71, 176-182. [CrossRef]

29. Wang, Y.; Zang, W.; Ji, S.; Cao, J.; Sun, C. Three Polymethoxyflavones purified from Ougan (Citrus reticulata Cv. Suavissima) inhibited LPS-Induced NO elevation in the neuroglia BV-2 cell line via the JAK2/STAT3 pathway. Nutrients 2019, 11, 791. [CrossRef]

30. Qi, G.; Mi, Y.; Fan, R.; Li, R.; Liu, Z.; Liu, X. Nobiletin Protects against systemic inflammation-stimulated memory impairment via MAPK and NF-kB signaling pathways. J. Agric. Food Chem. 2019, 67, 5122-5134. [CrossRef]

31. Matsuzaki, K.; Yamakuni, T.; Hashimoto, M.; Haque, A.M.; Shido, O.; Mimaki, Y.; Sashida, Y.; Ohizumi, Y. Nobiletin restoring beta-amyloid-impaired CREB phosphorylation rescues memory deterioration in Alzheimer's disease model rats. Neurosci. Lett. 2006, 400, 230-234. [CrossRef] [PubMed]

32. Singh, S.P.; Wahajuddin; Tewari, D.; Patel, K.; Jain, G.K. Permeability determination and pharmacokinetic study of nobiletin in rat plasma and brain by validated high-performance liquid chromatography method. Fitoterapia 2011, 82, 1206-1214. [CrossRef] [PubMed]

33. Lee, Y.S.; Cha, B.Y.; Choi, S.S.; Choi, B.K.; Yonezawa, T.; Teruya, T.; Nagai, K.; Woo, J.T. Nobiletin improves obesity and insulin resistance in high-fat diet-induced obese mice. J. Nutr. Biochem. 2013, 24, 156-162. [CrossRef] [PubMed]

(C) 2019 by the authors. Licensee MDPI, Basel, Switzerland. This article is an open access article distributed under the terms and conditions of the Creative Commons Attribution (CC BY) license (http://creativecommons.org/licenses/by/4.0/). 